\title{
Daya Hambat Ekstrak Biji Kopi Robusta (Coffea Canephora) terhadap Bakteri Porphyromonas gingivalis (in vitro)
}

(Minimum Inhibitory Effect Robusta Coffee Seeds (Coffea canephora) Extract towards Porphyromonas gingivalis (in vitro))

Rr. Nektara Titan Dianastri ${ }^{1}$, Pudji Astuti ${ }^{2}$, Rendra Chriestedy Prasetya ${ }^{2}$

1 Fakultas Kedokteran Gigi, Universitas Jember

2 Bagian Biomedik, Fakultas Kedokteran Gigi, Universitas Jember

\section{Abstrak}

Periodontitis disebabkan oleh plak dan bakteri Pophyromonas gingivalis sebagai penyebab utama. Lapisan membran terluar dinding Porphyromonas gingivalis memproduksi faktor virulensi patogenik, seperti lipopolisakarida yang mengaktivasi sel inflamasi dan menyebabkan fagositosis antigen sehingga memicu radikal bebas. Biji kopi robusta memiliki kandungan kafein, senyawa fenolik, trigonellin, dan asam khlorogenik sebagai antibakteri dan antiiinflamasi. Tujuan penelitian ini adalah untuk mengetahui daya hambat ekstrak biji kopi robusta (Coffea canephora) $0,5 \% ; 0,75 \% ; 1 \% ; 1,25 \% ; 1,5 \%$ dan $3 \%$ terhadap pertumbuhan Porphyromonas gingivalis secara in vitro dan mengetahui konsentrasi terendah ekstrak biji kopi Robusta (Coffea canephora) yang mempunyai daya hambat terhadap pertumbuhan Porphyromonas gingivalis. Pada penelitian ini dibagi 8 kelompok perlakuan yaitu kontrol positif (chlorhexidine), kontrol negatif (aquades steril), ekstrak biji kopi robusta 0,5\%, 0,75\%, 1\%, 1,25\%, 1,5\% dan 3\%. Petridish steril berisi media TSA ditambahkan suspensi $P$. gingivalis dengan kepadatan sesuai standar Mc. Farland. Blankdisk steril putih bulat berdiameter $6 \mathrm{~mm}$ diletakkan diatas media pertumbuhan dan ditetesi 8 bahan perlakuan. Setelah 24 jam diinkubasi dalam desikator, diamati dan dilakukan pengambilan data daya hambat esktrak biji kopi robusta terhadap pertumbuhan Porphyromonas gingivalis dengan mengukur zona hambatnya menggunakan jangka sorong. Hasil penelitian didapatkan ekstrak biji kopi robusta konsentrasi $3 \%, 1,5 \%, 1,25 \%$ dan $1 \%$, mempunyai daya antibakteri diduga karena biji kopi robusta mengandung kafein, polifenol dan asam khlorogenik yang memiliki aktifitas antibakteri sedangkan ekstrak biji kopi robusta konsentrasi $0,5 \%$ dan $0,75 \%$ tidak mempunyai daya antibakteri terhadap Pophyromonas gingivalis. Ekstrak biji kopi robusta konsentrasi $1 \%$ adalah konsentrasi terkecil ekstrak biji kopi Robusta (Coffea canephora) yang dapat menghambat pertumbuhan Porphyromonas gingivalis.

Kata Kunci : daya hambat minimal, ekstrak biji kopi robusta, Porphyromonas gingivalis,

\section{Abstract}

Periodontitis is mostly caused by plaque and Pophyromonas gingivalis bacteria as the main cause. The outer membrane layer of the Porphyromonas gingivalis wall produces pathogenic virulence factors, such as lipopolysaccharides which will activate inflammatory cells and cause phagocytosis of antigens thereby triggering free radicals. Robusta coffee beans naturally contain caffeine, phenolic compounds, trigonellin, and chlorogenic acids as antibacterial and anti-inflammatory. The purpose of this study was to determine the inhibition of Robusta (Coffea canephora) coffee bean extract $0.5 \%$; $0.75 \%$; $1 \%$; $1.25 \%$; $1.5 \%$ and $3 \%$ on the growth of Porphyromonas gingivalis in vitro and to find out the lowest concentration of Robusta (Coffea canephora) coffee bean extract which has inhibitory effect on the growth of Porphyromonas gingivalis. In this study were divided into 8 treatment groups namely positive control, negative control, $0.5 \%$ robusta coffee bean extract, $0.75 \%, 1 \%, 1.25 \%, 1.5 \%$ and $3 \%$. Petridish dishes containing TSA media that have been sterilized, added $P$. gingivalis suspension with density according to Mc standard. Farland Then a sterile white test blank with a diameter of $6 \mathrm{~mm}$ that is still sterile is placed on top of the bacterial growth media in accordance with the placement of the treatment group and dropped with all 8 treatment materials. After 24 hours incubated in a desiccator, the inhibition of robusta coffee bean extracts against the growth of Porphyromonas gingivalis bacteria was observed and data collection was done by measuring the inhibition zone using calipers. The results obtained robusta coffee bean extract at concentrations of $3 \%, 1.5 \%, 1.25 \%$ and $1 \%$, have an antibacterial power which is suspected because Robusta coffee beans naturally contain ingredients such as caffeine, polyphenols and chlorogenic acids which have antibacterial activity while the robusta coffee bean extract with a concentration of $0.5 \%$ and $0.75 \%$ does not have antibacterial power against Pophyromonas gingivalis. Robusta coffee bean extract with a concentration of $1 \%$ is the smallest concentration of Robusta (Coffea canephora) coffee bean extract which can inhibit the growth of Porphyromonas gingivalis.

Keywords : extract of robusta coffee seeds, minimum inhibitory capacity, Porphyromonas gingivalis

Korespondensi (Correspondence) : Rr. Nektara Titan Dianastri. Fakultas Kedokteran Gigi, Universitas Jember. Jl. Kalimantan 37 Jember 68121. Email : nektara_titan@yahoo.co.id

Penyakit periodontal banyak diderita oleh manusia hampir diseluruh dunia dan mencapai $50 \%$ dari jumlah populasi dewasa. Prevalensi penyakit periodontal di Indonesia menduduki peringkat kedua penyakit gigi dan mulut yaitu sebesar 60\%.' Penyebab penyakit periodontal dapat dibagi menjadi dua yaitu penyebab primer dan sekunder. Penyebab primer dari penyakit periodontal adalah plak gigi.2
Tahap pembentukan plak terdiri atas 3 tahapan. Tahapan tersebut melalui serangkaian proses yaitu perlekatan glikoprotein pada email dan terjadinya pembentukan pelikel, perlekatan bakteri pada pelikel (kolonisasi awal), dan peningkatan banyaknya plak oleh kelipatan bakteri (kolonisasi akhir). ${ }^{3}$ Pada saat memasuki fase pematangan plak, komposisi bakteri dalam plak berubah dengan meningkatnya jumlah 
bakteri gram negative seperti Porphyromonas gingivalis. ${ }^{4}$

Plak dapat dihilangkan secara mekanis dan kimiawi. Penyikatan gigi merupakan metode yang efektif untuk menyingkirkan plak secara mekanis, tetapi penyikatan gigi saja tidak selalu cukup. Oleh karena itu, penggunaan bahan kimia tambahan dijadikan sebagai cara mengatasi kekurangan dalam pembersihan plak secara mekanis. Salah satunya sebagai agen antibakterial untuk mencegah dan mengurangi akumulasi plak adalah obat kumur. ${ }^{5}$

Saat ini telah banyak dilakukan penelitian mengenai bahan alam yang dimanfaatkan pada produk kesehatan gigi seperti obat kumur. Diantara bahan-bahan alami yang telah menunjukkan sifat antibakteri, kopi merupakan bahan yang paling popular dikonsumsi. 6 Pemilihan jenis kopi yang akan digunakan dalam penelitian ini adalah kopi Robusta karena merupakan jenis kopi yang banyak dijumpai di Indonesia khususnya di perkebunan daerah Jember. Selain itu dalam penelitian terbaru, biji kopi robusta merupakan salah satu spesies kopi yang komersial dan menunjukkan efektivitas yang lebih baik bila dibandingkan dengan spesies kopi arabika. ${ }^{7}$

Biji kopi secara alami mempunyai kandungan seperti kafein, polifenol dan asam khlorogenik yang memiliki aktifitas sebagai antibakteri dan anti-inflamasi. ${ }^{8}$ Polifenol yang diekstraksi dapat membantu dalam mencegah penyakit mulut, terutama yang berhubungan dengan biofilm. Selain polifenol kopi juga mengandung senyawa kafein yang memperkuat pertahanan imun terhadap bakteri dan menstimulasi aktivitas lisozim, yang telah menunjukkan aktivitas bakterisidal. Kopi mengandung senyawa trigonelline, komponen larut air yang berkontribusi terhadap aroma dan rasa, berperan sebagai antiadhesive. ${ }^{9}$

Pada penelitian ini, peneliti mengunakan beberapa variasi konsentrasi ekstrak biji kopi Robusta. Berdasarkan penelitian yang dilakukan sebelumnya oleh Maharani (2015) didapatkan hasil bahwa berkumur dengan obat kumur yang mengandung ekstrak biji kopi robusta dengan konsentrasi 1,5\% efektif dalam menurunkan akumulasi plak dibanding hanya melakukan kontrol plak dengan menyikat gigi. Maka pada penelitian ini peneliti menggunakan beberapa konsentrasi ekstrak biji kopi robusta yaitu $0,75 \% ; 1 \% ; 1,25 \% ; 1,5 \%$ dan $3 \%$ untuk mendapatkan konsentrasi yang lebih minimal ekstrak biji kopi Robusta untuk menurunkan akumulasi bakteri P.gingivalis yang di lakukan secara in vitro.

\section{METODE PENELITIAN}

Jenis penelitian ini merupakan penelitian eksperimental laboratoris yang dilakukan dengan menggunakan posttest control group design untuk mengetahui perbedaan antara kelompok perlakuan dan kontrol (Sugiyono, 2017). Penelitian dilaksanakan pada bulan Oktober sampai November 2019 di laboratorium bioscience rumah sakit gigi dan mulut universitas jember.

\section{Pembuatan ekstrak biji kopi robusta}

Biji kopi robusta diseleksi dan ditimbang, kemudian di cuci dan sikeringkan dengan cara di angin-aginlan, setelahitu yang sudah kering ditimbang menggunakan neraca timbang sebanyak 300gram utuk di lakukan penghalusan agar menjadi serbuk. Kemudian dilakukan maserasi dengan ditambahkan larutan etanol $96 \%$ sebanyak $1200 \mathrm{ml}$ selama 24jam dengan menggunakan shaker bath. Setelah itu disaring menggunakan kertas saring dan didapatkan $750 \mathrm{ml}$, dan selanjutnya dipekatkan menggunakan rotary evaporator sehingga didapatkan ekstrak padat sebanyak 20.18 gram dengan konsentrasi $100 \%$. Peracikan ekstrak biji kopi robusta:

\section{Rumus: $\quad M 1 \times V 1=M 2 \times V 2$}

Membuat sediaan ekstrak $50 \%$ agar memudahkan dalam pelarutan dan perhitungan ekstrak. Igram ekstrak dilarutkan dalam $1 \mathrm{ml}$ aquades yang telah ditambah dengan propilenglikol sebanyak $10 \%$

\section{Pengujian daya hambat}

Setelah 24jam, petridish yang telah diberi perlakuan dikeluarkan dari desikator, kemudian dilakukan pengukuran zona hambat terhadap pertumbuhan $P$. gingivalis (daerah inhibisi). Pengukuran daerah inhibisi yaitu dengan membalikkan petridish sehingga terlihat daerah hambatan yang terlihat transparan disekitar lubang sumuran, kemudian dengan menggunakan jangka sorong daerah inhibisi diukur diameternya dan dicatat.

Data hasil penelitian dianalisis menggunakan SPSS 26.0 kemudian dilakukan uji normalitas uji Shapirowilk dan uji homogenitas dengan Levene Test. Data yang diperoleh terdistribusi normal dan tidak homogen kemudian dilanjutkan dengan uji statistic non parametric Kruskal-Wallis $(p>0,05)$ dan dilanjutkan dengan uji Mann Whitney ( $p>0,05)$.

\section{HASIL}

Tabel 1 menunjukkan bahwa nilai rararata diameter zona hambat berturut-turut mulai dari yang terbesar adalah pada kontrol 
positif $20.97 \mathrm{~mm}$, kemudian ekstrak biji kopi robusta $3 \%$ sebesar $19.28 \mathrm{~mm}$, ekstrak biji kopi robusta $1,5 \%$ sebesar $18.43 \mathrm{~mm}$, ekstrak biji kopi robusta $1,25 \%$ sebesar $17.51 \mathrm{~mm}$, ekstrak biji kopi robusta $1 \%$ sebesar $14.68 \mathrm{~mm}$ dan pada ekstrak biji kopi robusta konsentrasi $0,75 \%, 0,5 \%$ dan kontrol negatif tidak ditemukan adanya zona hambat

Tabel 1. Hasil Pengukuran rata-rata diameter zona hambat ekstrak biji kopi Robusta terhadap pertumbuhan P.gingivalis

\begin{tabular}{|c|c|c|c|}
\hline & $\mathbf{N}$ & $\overline{\mathrm{X}}$ & SD \\
\hline Aquadest Steril K (-) & 8 & 0,00 & 0,00 \\
\hline Ekstrak $0,5 \%$ & 8 & 0,00 & 0,00 \\
\hline Ekstrak $0,75 \%$ & 8 & 0,00 & 0,00 \\
\hline Ekstrak $1 \%$ & 8 & 14,68 & 0,90 \\
\hline Ekstrak 1,25\% & 8 & 17,51 & 1,71 \\
\hline Ekstrak 1,5\% & 8 & 18,43 & 0,79 \\
\hline Ekstrak 3\% & 8 & 19,28 & 1,01 \\
\hline Chlorhexidine K (+) & 8 & 20,97 & 1,46 \\
\hline
\end{tabular}

$\mathrm{N}$, Jumlah sampel; $\mathrm{x}=$ Nilai rata-rata diameter zona hambat; $S D=$ Standar deviasi diameter zona hambat

Berdasarkan analisis kruskal wallis menunjukkan 0,00 , yang berarti bahwa ratarata diameter zona hambat dalam kelompok memiliki perbedaan yang bermakna. Hasil uji Mann Whitney dapat dilihat pada table 2. Berdasarkan hasil tersebut didapatkan hasil yang bervariatif. Ada perbedaan yang signifikan antar beberapa kelompok perlakuan tetapi ada beberapa kelompok yang hasilnya tidak signifikan yaitu perbandingan antara kelompok $K(-)$, ekstrak biji kopi robusta 0,5\% dan ekstrak biji robusta $0,75 \%$ serta perbandingan antara kelompok $1,25 \%$ dengan kelompok 1,5\% yang memiliki perbedaan tidak bermakna.

\section{PEMBAHASAN}

Pada penelitian ini dalam melarutkan ekstrak biji kopi robusta digunakan pelarut etanol $96 \%$. Flavonoid yang terkandung dalam biji kopi robusta berupa senyawa yang larut di dalam air dan dapat diekstraksi dengan etanol. ${ }^{5}$ Pelarut etanol $96 \%$ merupakan pelarut universal yang aman dan baik untuk ekstraksi semua golongan senyawa metabolit sekunder, sehingga dapat melarutkan seluruh bahan aktif yang terkandung di dalam suatu bahan alami seperti kopi robusta. 10 Propilenglikol sebanyak $10 \%$ ditambahkan dalam larutan sebagai pelarut dan suspending agent bertujuan untuk meningkatkan viskositas dan memperlambat pengendapan sehingga menghasilkan suspense yang stabil. ${ }^{11}$

Hasil penelitian menunjukkan bahwa pada kelompok ekstrak biji kopi robusta konsentrasi $1 \%, 1,25 \%, 1,5 \%$ dan $3 \%$ terdapat zona hambat yang dapat diartikan bahwa pada konsentrasi ini ekstrak biji kopi robusta dapat menghambat pertumbuhan P.gingivalis. Dari hasil yang didapat, diduga bahwa ekstrak biji kopi Robusta memiliki kandungan antibakteri plak yakni asam klorogenik, caffeid acid, polifenol dan kafein. Asumsi ini dikuatkan oleh penelitian yang dilakukan oleh Luoet dalam Maheswari (2014) menyebutkan bahwa asam klorogenik dapat menghambat bakteri jenis gram positif maupun gram negatif. Asam klorogenik sebagai antibakteri masuk ke dalam sel dan merusak struktur dinding sel bakteri yang akan menyebabkan bakteri lisis atau mati.10 Dalam penelitian lain, ekstrak biji kopi Robusta juga terkandung adanya caffeic acid. Meskipun kadar caffeic acid dalam ekstrak biji kopi Robusta lebih sedikit, peran senyawa ini juga penting dalam proses penghambatan pertumbuhan koloni bakteri. ${ }^{11}$

Terdapat pula senyawa trigonelin yang merupakan antibakteri paling efektif dari senyawa yang terdapat pada biji kopi robusta. Senyawa trigonelin dan turunannya memiliki daya antibakteri paling tinggi terhadap semua bakteri pathogen yang terdapat di rongga mulut. ${ }^{2}$ Selain menghambat sintesis enzim dan protein pada bakteri, trigonelin juga dapat menghambat pertumbuhan bakteri dengan

Tabel 2. Hasil uji beda rata-rata sampel zona hambat biji kopi Robusta terhadap pertumbuhan

\begin{tabular}{lcccccccc}
\multicolumn{1}{c}{ P.gingivalis } \\
\multicolumn{1}{c}{ Kelompok } & $\mathbf{K}(-)$ & $\begin{array}{c}\text { Ekstrak } \\
\mathbf{0 , 5 \%}\end{array}$ & $\begin{array}{c}\text { Ekstrak } \\
\mathbf{0 , 7 5 \%}\end{array}$ & $\begin{array}{c}\text { Ekstrak } \\
\mathbf{1 \%}\end{array}$ & $\begin{array}{c}\text { Ekstrak } \\
\mathbf{1 , 2 5 \%}\end{array}$ & $\begin{array}{c}\text { Ekstrak } \\
\mathbf{1 . 5 \%}\end{array}$ & $\begin{array}{c}\text { Ekstrak } \\
\mathbf{3 \%}\end{array}$ & $\mathbf{K}(+)$ \\
\hline K (-) & - & 1.000 & 1.000 & $0.000^{*}$ & $0.000^{*}$ & $0.000^{*}$ & $0.000^{*}$ & $0.000^{*}$ \\
Ekstrak 0,5\% & 1.000 & - & 1.000 & $0.000^{*}$ & $0.000^{*}$ & $0.000^{*}$ & $0.000^{*}$ & $0.000^{*}$ \\
Ekstrak 0,75\% & 1.000 & 1.000 & - & $0.000^{*}$ & $0.000^{*}$ & $0.000^{*}$ & $0.000^{*}$ & $0.000^{*}$ \\
Ekstrak 1\% & $0.000^{*}$ & $0.000^{*}$ & $0.000^{*}$ & - & 0.003 & 0.001 & $0.001^{*}$ & $0.001^{*}$ \\
Ekstrak 1,25\% & $0.000^{*}$ & $0.000^{*}$ & $0.000^{*}$ & $0.003^{*}$ & - & 0.092 & $0.036^{*}$ & $0.003^{*}$ \\
Ekstrak 1,5\% & $0.000^{*}$ & $0.000^{*}$ & $0.000^{*}$ & $0.001^{*}$ & 0.092 & - & $0.035^{*}$ & $0.001^{*}$ \\
Ekstrak 3\% & $0.000^{*}$ & $0.000^{*}$ & $0.000^{*}$ & $0.001^{*}$ & $0.036^{*}$ & $0.035^{*}$ & - & $0.07^{*}$ \\
K (+) & $0.000^{*}$ & $0.000^{*}$ & $0.000^{*}$ & $0.001^{*}$ & $0.003^{*}$ & $0.001^{*}$ & $0.007^{*}$ & - \\
\hline
\end{tabular}

*,ada perbedaan bermakna; $\mathrm{K}(-)$, kontrol negative/ pemberian akuades steril; $\mathrm{K}(+)$, pemberian klorheksidin

menghambat pembentukan bakteri dengan cara mengganggu stabilitas membran sitoplasmanya yang berakibat pada tidak seimbangnya fungsi metabolisme dari bakteri tersebut."11 
Senyawa lain pada biji kopi robusta yang berperan sebagai antibakteri adalah kafein. Kafein merupakan senyawa alkaloid yang berwujud kristal berwarna putih yang memiliki sifat antibakteri dengan melewati dinding sel bakteri.13 Kemampuan senyawa alkaloid sangat dipengaruhi oleh keaktifan biologis senyawa tersebut, yang disebabkan oleh adanya gugus basa yang mengandung nitrogen. Adanya gugus basa ini apabila mengalami kontak dengan bakteri akan bereaksi dengan senyawa asam amino yang menyusun dinding sel dan DNA bakteri yang merupakan penyusun utama inti sel, dimana merupakan pusat pengaturan segala kegiatan sel. Reaksi ini terjadi karena senyawa yang bersifat basa akan bereaksi dengan senyawa asam, dalam hal ini adalah asam amino yang akan menyebabkan terjadinya perubahan struktur dan susunan asam amino. ${ }^{14}$ DNA dan RNA bakteri yang semakin sedikit maka dapat mengakibatkan aktifitas yang lebih rendah pada semua sel bakteri, sehingga sintesis enzim dan protein tidak terjadi. Akhir dari mekanisme ini bakteri dapat mengakibatkan lisis atau mati.13

Sedangkan hasil diameter zona hambat tertinggi terdapat pada kelompok perlakuan kontrol positif yaitu obat kumur chlorhexidine. Ditunjang pada analisa data berbeda bermakna dengan semua kelompok ekstrak biji kopi robusta. Berdasarkan penelitian Sinaredi, (2014) clhorhexidine memiliki rerata diameter zona hambat terbesar dibandingkan fluoride dan povidone iodine. Hal tersebut disebabkan karena mekanisme kerja chlorhexidine efektif menghambat pertumbuhan maupun membunuh bakteri gram positif 10 dan memiliki peranan penting dalam membunuh mikroorganisme gram negatif anaerob misalnya porphyromonas gingivalis. Dasar yang kuat untuk mencegah terbentuknya plak adalah terjadinya ikatan antara chlorhexidine dengan molekul permukaan gigi antara lain polisakarida, protein, glikoprotein, saliva, pelikel, mukosa serta permukaan hidroksiapatit. ${ }^{13}$ Chlorhexidine akan menyebabkan perubahan pada permeabilitas membran sel bakteri sehingga menyebabkan keluarnya sitoplasma sel dan komponen sel dengan berat molekul rendah dari dalam sel menembus membran sel sehingga menyebabkan kematian bakteri ${ }^{6}$ Akibat adanya ikatan tersebut maka pembentukan plak dihambat. ${ }^{13}$

Pada kelompok ekstrak biji kopi robusta konsentrasi $1 \%, 1,25 \%, 1,5 \%$ dan $3 \%$ terdapat zona hambat yang berbeda dengan zona hambat paling tinggi adalah $3 \%$ dan paling rendah adalah $1 \%$. Pada konsentrasi $0,75 \%$ serta $0,5 \%$ tidak ditemukan adanya zona hambat. Hal ini diduga disebabkan oleh besarnya konsentrasi ekstrak biji kopi Robusta akan mempengaruhi banyaknya kandungan zat aktif di dalam suatu bahan. ${ }^{13}$ sehingga kemampuan ekstrak biji kopi robusta sebagai antibakteri semakin kuat.

Berdasarkan hasil penelitian yang diperoleh, dapat disimpulkan bahwa ekstrak biji kopi robusta pada konsentrasi 1\%, 1,25\% , $1,5 \%$, dan $3 \%$, mempunyai daya antibakteri terhadap P. gingivalis dan ekstrak biji kopi robusta dengan konsentrasi $1 \%$ adalah konsentrasi terkecil dari ekstrak biji kopi Robusta (Coffea canephora) yang dapat menghambat pertumbuhan Porphyromonas gingivalis

Saran yang dapat diberikan dari hasil penelitian ini adalah

1. Perlu dilakukan penelitian lebih lanjut secara in vivo dengan menggunakan ekstrak biji kopi Robusta sebagai obat kumur

2. Perlu dilakukan penelitian lebih lanjut mengenai kandungan ekstrak biji kopi Robusta untuk mengetahui zat aktif yang berguna sebagai antibakteri terhadap bakteri jenis lain.

\section{DAFTAR PUSTAKA}

1. Sugiarti T. Kejadian Periodontitis di Kabupaten Magelang. Higeia Journal of Public Health Research and Development. 2017.

2. Dewi RAP dan Wibisono G. Pengaruh Pasta Gigi dengan Kandungan Buah Apel (Pyrus malus) terhadap Pembentukan Plak Gigi. Universitas Diponegoro. 2011.

3. Carranza. Clinical Periodontology. 11th Ed. Philadelphia: W.B.Saunders Co. 2012.

4. Newman, M., Takei, H., Klokkevold P., dan Carranza, F. Carranza's Clinical Periodontology. Twelfth Edition. St Louis:Elsevier. 2015.

5. Maharani J. Efektivitas Ekstrak Biji Kopi Robusta (Coffea canephora) 1,5\% sebagai Obat Kumur terhadap Akumulasi Plak Mahasiswa Fkg Usu Angkatan 2014. Universitas Sumatra Utara. 2015.

6. Antonio AG, lorio NLP, Pierro VSS, Candreva MS, dos Santos KRN, Maia LC, Farah A. Inhibitory Properties Of Coffea canephora Extract Against Oral Bacteria And Its Effect On Demineralisation of Deciduous Teeth. Archives of Oral Biology 56. 2012.

7. Mehta VV, Rajesh G, Rao A, Shenoy R, Pai M. Antimicrobial efficacy of Punica Granatum mesocarp, Nelumbo nucifera leaf, Psidium guajava leaf and Coffea Canephora extract on common oral 
pathogens: An In-Vitro Study. Journal of Clinical and Diagnostic Research. 2014; 8(7): 65

8. Ermawati T. Potensi Gel Ekstrak Biji Kopi Robusta (Coffea Robusta) terhadap Ekspresi Tnf-A pada Tikus Periodontitis yang di Induksi Porphyromonas gingivalis. Universitas Jember. 2013

9. Namboodiripad PCA, Kori S. Can coffee prevent caries?. Journal of Conservative Dentistry. 2009; 12(1):17

10. Lubis MR. Pengaruh Konsentrasi Ekstrak Biji Kopi Robusta (Coffea canephora) Terhadap Ph Saliva dan Pertumbuhan Bakteri Staphylococcus Aureus (In Vitro). Universitas Sumatera Utara. 2018.

11. Maheswari RA. Daya hambat ekstrak biji kopi robusta (Coffea canephora) terhadap pertumbuhan bakteri plak. Universistas Airlangga. 2014.

12. Tanauma HA. Aktivitas antibakteri ekstrak biji kopi robusta (Coffea canephora) terhadap bakteri Escherichia coli. Pharmacon Jurnal Ilmiah Farmasi. UNSRAT. 2016; 5: 4.

13. Yaqin MA, Nurmilawati M. Pengaruh Ekstrak Kopi Robusta (Coffea robusta) sebagai Penghambat Pertumbuhan Staphylococcus aureus. Universitas Nusantara PGRI Kediri. 2015.

14. Gunawan IWA. Potensi Buah Pare (Momordica Charantia L) Sebagai Antibakteri Salmonella typhimurium. Denpasar: Program Studi Pendidikan Biologi Fakultas Keguruan dan IImu Pendidikan Universitas Mahasaraswati. 2009 